\title{
Study on Rescue and Disposal Measures against Nitro-compound Accidents
}

\author{
Zefu $\mathrm{He}^{\mathrm{a}}$ and Zhiming Ren ${ }^{\mathrm{b}^{*}}$ \\ Kunming Fire Service Training School \\ afzhy2003@126.com, ${ }^{\mathrm{b}} 913821250 @ q q . c o m$
}

*The corresponding author

Keywords: Fire; Nitro-compound; Rescue; Disposal measure

\begin{abstract}
With the rapid development of Chinese chemical industry, nitro-compound accidents happen frequently and cause great harm, which are easy to result in explosion, poisoning and other secondary accidents with disposal difficulty. In this paper, by analyzing the physical and chemical properties of nitro-compounds, combined with the typical cases happened in recent years, we studied the fire rescue technologies of such accidents and proposed disposal measures against the leakage and explosion accidents of nitro-compounds.
\end{abstract}

\section{Introduction}

It is well known that nitro-compounds are important chemical raw materials, which are widely used in industries of pesticides, medicine, explosive, dye, chemical fiber, rubber and so on[1-2]. In addition, nitro-compounds can be applied as intermediates with high activity to produce a series of chemical products through the reduction, hydration and nucleophilic addition reactions of.

Due to the extensive use of nitro-compounds, disasters and accidents happened frequently. For example, the explosion of nitro-guanidine, guanidine nitrate occurred in Kerr Chemical Co., Ltd. in Zhao County, Shijiazhuang city of Hebei Province on 2012 February 28th, resulting in 25 people dead, 4 people missing and 46 people wounded. Nitro-compound accidents are generally divided into leakage and explosion. How to carry out scientific rescue according to characteristics of danger is the core task for fire officers and soldiers. This paper studied how the firemen carry out the initial disposal immediately, and take reasonable technical tactics according to the situation of the accident, as well as a typical case analysis of disposal measures against nitro-compound accidents, hoping to guide the rescue of such accidents.

\section{Chemical and Physical Properties}

Hydrocarbon whose hydrogen atom is replaced by nitro group $\left(-\mathrm{NO}_{2}\right)$ is called nitro-compound[3], which can be divided into aliphatic nitro-compound $\left(\mathrm{R}-\mathrm{NO}_{2}\right)$ and aromatic nitro-compound $\left(\mathrm{Ar}-\mathrm{NO}_{2}\right)$ according to the different hydroxyl groups. Since the nitro group is a strong electron-withdrawing group, nitro-compound has large values of dipole moment, polarity and intermolecular attraction. Therefore, the aliphatic nitro-compounds are colorless or slightly yellow liquids with high boiling point, while nitro-compounds are generally crystalline solids and mostly yellow. Nitro-compounds can be used as industrial raw materials for medicine, dyes, spices, explosives and organic synthesis reagents. The greatest risk is the nitro-compounds are toxic and explosive, whose vapor can be absorbed through the skin, leading to the body poisoning. Polynitro-compounds, such as trinitrotoluene (TNT) and picric acid (TNP), are unstable in nature for their strong oxidation activity, and can be used as explosives.

\section{Disposal Measures against Nitro-Compound Leakage or Explosion Accident}

Most nitro compounds have the corresponding toxic and explosive hazards, especially nitro compounds and nitrates, are prone to explosion or fire under conditions of heat, friction, impact or 
contact with the fire source. Aliphatic nitro-compounds are flammable liquids with a lower flash point. The nitro compounds of benzene and its homologues among aromatic nitro compounds are combustible liquids or combustible solids. When subjecting to heat, friction or strong impact, dinitro and polynitro-compounds are extremely unstable, having great destructive power for the possible decomposition after the explosion. The sequence of their explosive activities is as follows: O-nitro-compounds $>\mathrm{N}$-nitro-compounds $>$ C-nitro-compounds. At room temperature, only $2 \mathrm{~J} / \mathrm{cm}^{2}$ mechanical impact energy on nitroglycerin can cause explosion[4]. Dry nitrocellulose which can burn spontaneously, cab catch fire immediately by the flame, and even may explode in case of a large amount of burning.

Disposal Measures against Leakage Accident. The aliphatic nitro-compounds are colorless or slightly yellow liquids with higher boiling point[5]. After leaking, the steams of such nitro-compounds can burn and explode in case of heat or flame. The polynitro-compounds are yellow solids, usually explosive, such as trinitrotoluene (TNT) used as explosives, while other nitro-compounds have a fragrance, such as xylene, and can be used as spices. Most of nitro-compounds are toxic, and can cause poisoning through the effect of Hemoglobin in the blood after skin contact or respiratory inhalation[6].

After the accident, according to the liquid flow and the area affected by diffusion of steam and dust, the fire officers and soldiers should immediately delimit the alter area to restricted personnel access, evacuate unrelated people from the side wind and windward places to the safe areas[7], eliminate all ignition sources, wear gas protecting clothing and air breathing apparatus. The damaged container and spillage should not be touched before firemen wearing grade chemical protective clothing. Cut off the source as much as possible to prevent spillage into the water, sewer, basement or enclosed space[8]. For a small amount of leakage, materials of dry sand or other incombustible material for absorbing or covering the spillage can be collected in a container. It is also available to rinse the spillage with plenty of water, then charge it into the waste water system, or absorb it with inert, damp non-combustible material absorption [9]. As for a large amount of leakage, it is necessary to build dike, dig hole or absorb with lime powder to dispose leakage. The separation distance is at least $100 \mathrm{~m}$ for the liquid and at least $25 \mathrm{~m}$ for the solid. In case of a large number of leaks, the initial evacuation distance at the downwind direction is further increased on the basis of the isolation distance [10].

Nitro-compounds with explosive dangerous are prohibited to be covered with sand. It is forbidden to use nitrite, foam fire extinguishing agents to deal with flammable solids producing toxic or irritating gases in water or acids, such as nitrocellulose, nitrogen compounds, trinitrotoluene, etc.

In general, the principle of nitro-compounds disposal is as follows: Wear air respirators or gas masks, do not smoke near the leaking area, and eliminate all open flames, sparks or flames, do not contact nor across the spillage. Plug the leak or flip the leaked container to prevent leaking in the premise of security. Spray water to suppress steam or to change the direction of the vapor cloud. It is prohibited to rinse the spillage or leakage directly with water. Prevent the steam of spillage from passing through the sewer, ventilation system and the airtight space to the leakage isolation area until the gas is scattered. For the disposal of spillage, dust should be avoided, and collected in a dry, clean, covered containers with a clean shovel, can also be covered with plastic cloth, canvas, and then collected or transported to the professional disposal places handling dangerous chemicals. 
Table 1 Typical disposal cases of nitro-compound leakage accidents

\begin{tabular}{|c|c|c|c|c|}
\hline NO. & Date & Location & Accident & Disposal measures \\
\hline 1 & $\begin{array}{l}2016.1 .1 \\
3\end{array}$ & $\begin{array}{l}327 \text { Provincial } \\
\text { Highway, East } \\
\text { County }\end{array}$ & $\begin{array}{l}\text { O-nitro-chlorinated } \\
\text { benzene leakage }\end{array}$ & $\begin{array}{l}\text { Dilute and cool the materials with water } \\
\text { gun for solidification and plugging. }\end{array}$ \\
\hline 2 & $\begin{array}{l}2014.2 .2 \\
4\end{array}$ & $\begin{array}{l}\text { Hangzhou Bay, } \\
\text { Shaoxing }\end{array}$ & $\begin{array}{l}\text { Nitrobenzene } \\
\text { leakage }\end{array}$ & $\begin{array}{l}\text { 1. Dilute the leakage from the east, north } \\
\text { and west sides of the distillation column } \\
\text { with remote control water gun and water } \\
\text { gun equipped with shelves. } \\
\text { 2. Plug the leak with plastics and } \\
\text { plugging tools. }\end{array}$ \\
\hline 3 & $\begin{array}{l}2012.4 .1 \\
4\end{array}$ & $\begin{array}{l}\text { Baoji-Tianshui Expre } \\
\text { ssway }\end{array}$ & $\begin{array}{l}\text { Nitrobenzene tank } \\
\text { leakage }\end{array}$ & $\begin{array}{l}\text { 1.Extinguish the flowing fire with foam } \\
\text { gun. } \\
\text { 2.Control the fire with D.C water gun. } \\
\text { 3.Build dam with gravel and soil to } \\
\text { intercept polluted water and liquids. }\end{array}$ \\
\hline 4 & 2006.6 .9 & $\begin{array}{l}\text { Qingdao, Shandong } \\
\text { Province }\end{array}$ & $\begin{array}{l}\text { Nitrobenzene } \\
\text { leakage }\end{array}$ & $\begin{array}{l}\text { 1.Dilute the leakage area with water gun. } \\
\text { 2. Wrap the leak with plastic film and then } \\
\text { seal with plastic tape. } \\
\text { 3.Intercept the polluted water with dam } \\
\text { built mechanically or artificially. }\end{array}$ \\
\hline 5 & $\begin{array}{l}2001.7 .2 \\
7\end{array}$ & Zhenhai, Ningbo & $\begin{array}{l}\text { Nitrobenzene } \\
\text { leakage caused by } \\
\text { explosion }\end{array}$ & $\begin{array}{l}\text { 1.Extinguish the fire source directly from } \\
\text { the windward (south) with two foam guns. } \\
\text { 2.Extinguish the fire from the north side } \\
\text { with a foam gun. } \\
\text { 3.Cool from the east side with water } \\
\text { cannon and provide water. } \\
\text { 4.Plug with cotton yarn and plugging } \\
\text { glue. }\end{array}$ \\
\hline
\end{tabular}

Disposal Measures against Explosion Accidents. In the production process, especially in the distillation process, nitro-compounds are heated in a closed device, while the decomposition of nitro-compounds is exothermic reaction with gas products, in addition, the thermal decomposition has self-catalytic properties. Hence, the decomposition rate will be faster and faster. Therefore, the danger of the explosion is great. In the event of an accident during the transport process, nitro-compounds may form toxic and flammable vapors, and both sparks and pyrotechnics should be eliminated for the first time at the site to prevent the release of the vapor from causing the explosion [11]. Explosion caused by the fire should be extinguished with dry powder, carbon dioxide, mist water, anti-soluble foam. Exposed parts or sites endangering the safety of human body should be provided with protective cover, safety barrier baffle to prevent unrelated personnel approaching. It is necessary to build dike or dig holes to collect spillage and waste water. 
Table 2 Typical disposal cases of nitro-compounds explosion accidents

\begin{tabular}{|c|c|c|c|c|}
\hline NO. & Date & Location & Accident & Disposal measures \\
\hline 1 & 2015.10 . & $\begin{array}{l}\text { Shangyu, } \\
\text { Shaoxing City }\end{array}$ & $\begin{array}{l}\text { 2-4 Dinitrochlorobenzene } \\
\text { explosion }\end{array}$ & $\begin{array}{l}\text { 1.Spray mist water from windward of } \\
\text { high jet car. } \\
\text { 2.Cool with two remote control water } \\
\text { cannons on one side. } \\
\text { 3.Extinguish the fire with foam gun on } \\
\text { the other side. }\end{array}$ \\
\hline 2 & 2013.4 .23 & $\begin{array}{l}\text { Chifeng, } \\
\text { Neimenggu }\end{array}$ & $\begin{array}{l}\text { Phosphonitrobenzene } \\
\text { bromide combustion } \\
\text { explosion }\end{array}$ & $\begin{array}{l}\text { 1.Cool and dilute with mist water. } \\
\text { 2. Extinguish the fire with dry powder. } \\
\text { 3.Cover the flowing fire with sand and } \\
\text { soil. }\end{array}$ \\
\hline 3 & $\begin{array}{l}2012.11 .2 \\
8\end{array}$ & $\begin{array}{l}\text { Fan County, } \\
\text { Puyang City }\end{array}$ & $\begin{array}{l}\text { P-nitrophenolate sodium } \\
\text { burning explosion }\end{array}$ & $\begin{array}{l}\text { 1.Mainly fight the fire on the third floor } \\
\text { of the factory building from the } \\
\text { windward with High spray fire monitor. } \\
\text { 2. Extinguish the fire on the north side of } \\
\text { the factory building with an auxiliary } \\
\text { foam gun. } \\
\text { 3.Extinguish the fire on the first floor } \\
\text { with gravel. } \\
\text { 4.Order the factory staff to transport } \\
\text { materials. }\end{array}$ \\
\hline 4 & 2012.2 .28 & $\begin{array}{l}\text { Zhao County, Shi } \\
\text { Jiazhuang City }\end{array}$ & $\begin{array}{l}\text { Nitroguanidine, } \\
\text { guanidine nitrate } \\
\text { explosion }\end{array}$ & $\begin{array}{l}\text { 1. Wash the site with chemical washing } \\
\text { car. } \\
\text { 2.Extinguish the fire directly with foam } \\
\text { gun. } \\
\text { 3. Organize personel and resource to } \\
\text { rescue } \\
\text { 4.Set up evacuate signal. } \\
\text { 5.Clean up the explosion site. }\end{array}$ \\
\hline 5 & 2009.7.15 & $\begin{array}{l}\text { Guxian Town, } \\
\text { Luoyang City }\end{array}$ & $\begin{array}{l}\text { 2,4-Dinitrochlorobenzene } \\
\text { explosion }\end{array}$ & $\begin{array}{l}\text { 1.Suppress and extinguish the fire with } \\
\text { high spray fire monitor in close } \\
\text { distance. } \\
\text { 2.Extinguish the fire nearly with foam } \\
\text { gun. } \\
\text { 3.Cool and dilute with D.C water. }\end{array}$ \\
\hline 6 & 2007.5.11 & Cangzhou City & Nitrotoluene explosion & $\begin{array}{l}\text { 1.Dilute with mist water. } \\
\text { 2.Cool with D.C water. } \\
\text { 3.Cut off the material by close he valve. } \\
\text { 4.Extinguish the fire with foam gun. }\end{array}$ \\
\hline
\end{tabular}

\section{Safety Precautions During Nitro-Compound Accident Disposition}

Due to leakage or explosion of nitro-compounds, toxic and hazardous substances or secondary accidents can be produced, hurting the environment and people's lives and property correspondingly. Hence, the fire officers and soldiers in the disposal of such accidents should pay attention to the following points.

Correctly Choose the Driving Route, Parking Location and Fighting Position to Enter the Scene. Strictly control all fire sources in hazardous areas and the number of the stuff carrying out 
emergency operations in the heavily hazardous area. Strictly prevent the disposal stuff from staying at the top of the underground space, such as sewers, wellhead in the leakage area.

Arrange on-site Security Officer to Determine Emergency Hedge Signal, Monitor and Observe the Possible Dangerous Signs in the Whole Process at the Dangerous Area or Parts, and Immediately Conduct Emergency Shelter Once the Sudden Situation Happens. Hedging signals and measures used are as follows: Emergency withdrawal signal is sending notification three times with walkie-talkie or short siren whistling plus long light flashing. Emergency hedging measure is to evacuate along the water belt or take a shortcut quickly to a safe area. Explosion hazard signal is to send notification three times with walkie-talkie or long siren whistling plus long light flashing. Emergency hedge measures also include looking the nearest bunker or lying down.

Do a Good Washing Job on the Scene, Recycle and Bury the Polluted Liquid and Soil to Prevent the Environment pollution After Leak.

Consider Fully the Physical and Chemical Properties of the Material during the Selection of the Fire Extinguishing Agent and Fire-Fighting Method at the Scene, and take Full account of Opinions of the Professional and Technical Personnel.

Compose the Disposition Power Generally with the Fire Squadron as the Basic Combat Units, Which are Usually Set up with The Detection Group, Life Group, Cover Group, Plugging Group, Washing Group And Altering Group. Each Crew Must Not Be Less than 3 People, and Should Be Responsible for A Team Leader, with Preparation and Rotation Forces.

\section{References}

[1] Muller, W. E. The Benzodiazepine Receptor. Cambridge Town: Cambridge University Press, 1988.

[2] Belciug, M. Ananthanarayanan, V. S. J. Med. Chem., 1994, 37: 4392.

[3] Liu Xiuhua. Analysis of Nitro-compounds by HPLC[J]. Environmental Chemistry, 2012, 03.

[4] Yi Jingduan. Preparation of 1,1,1-tritroethane[J]. Fire and Explosive, 1996,02.

[5] Huang Zhenghua. Risk Analysis and Accident Prevention of the Explosion in the Fire during Nitrification Process [J]. Chemical Safety and Environment, 2004, 17(3): 14 -15.

[6] Li Shu. Fire Emergency Rescue [M]. Beijing: Higher Education Press, 2011.

[7] Wan Bentai. Emergency Monitoring and Disposal Technology of Sudden Environmental Pollution[M]. Beijing: China Environmental Press, 1996.

[8] Rao Yongcai. Case Study and Analysis of Emergency Monitoring of Nitrobenzene Leakage Accident in Sanhuan West Road of Xuzhou City[J]. Environmental Technologies, 2008(s2).

[9] Zhou Yundi. An Emergency Monitoring case of Styrene Tanker Leakage[J]. Jiangsu Environmental Technologies, 2008(04)

[10]Yang Zhifeng. Discussion of the Principle and Technical Essentials of Gas Explosion[J]. Coal Mine Safety, 2015(05) 